\title{
Impact of students' performance in the continuous assessment methodology through Moodle on the final exam
}

\author{
Impacto del desempeño de los estudiantes en una metodología \\ de evaluación continua en Moodle en el examen final
}

\author{
Paloma Merello-Giménez (paloma.merello@uv.es) \\ Accounting Department, University of Valencia, Spain. \\ Ana Zorio-Grima (ana.zorio@uv.es) \\ Accounting Department, University of Valencia, Spain. \\ http://dx.doi.org/10.12795/EDUCADE.2017.i08.05
}

\begin{abstract}
RESUMEN: Este trabajo examina la diferente evolución del rendimiento de los estudiantes en cuestionarios online y su impacto en la calificación final. Esta innovadora técnica se ha utilizado en un grupo de un curso introductorio de contabilidad financiera con 8 cuestionarios online (uno por unidad temática) a través de la plataforma Moodle. Empleando el análisis cluster, identificamos diferentes grupos de evolución del rendimiento. La evidencia obtenida sugiere que en uno de estos grupos una evolución favorable del rendimiento en los test online puede conducir a un exceso de confianza, con el posterior efecto negativo en la nota del examen final. La investigación futura con más variables y muestras de mayor tamaño ayudará a identificar este perfil de estudiante con el fin de evitar un posible efecto negativo no deseado de esta técnica de enseñanza.
\end{abstract}

PALABRAS CLAVE: Moodle; contabilidad; cuestionarios online; sobreconfianza.

\begin{abstract}
This paper looks into the different evolution of students' online questionnaire performance and its impact on the final examination mark. This innovative technique has been used in a group of an introductory financial accounting course with 8 online questionnaires (one per unit) in the Moodle platform. Using cluster analysis, we identify different groups of performance evolution. The evidence obtained suggests that in one of this groups a favourable test performance evolution may lead to overconfidence with the subsequent negative effect on the final examination mark. Future research with more variables and bigger samples will help to identify this student profile with a view to prevent this undesired negative effect of this teaching technique.
\end{abstract}

KEYWORDS: Moodle; accounting; online questionnaires, overconfidence.

The authors gratefully acknowledge financial support from the University of Valencia (UV-SFPIE_GER 16-4 15408).

Artículo. Recibido: 10-07-17 - Versión revisada: 21-07-17, Aceptado: 25-07-17

Versión inicial presentada en el HEAD '17 Conference

Licencia Creative Commons BY NC ND · 2017 · Asociación Española de Contabilidad y Administración de Empresas - AECA

\section{INTRODUCCIÓN}

In the European Higher Education Area (EHEA), the educational model should be student-centered (European Ministers of Education, 1999, Gonzalez, Arquero \& Hassall, 2009). Therefore, the student is the central axis of the teaching-learning process and 
must be aware that to achieve the necessary skills and abilities to pass the course, it is essential to be proactively involved in the process (Beltrá, Pereira \& Sáez, 2011).

With a traditional methodology based on the master class, the evaluation used to be based only on the final exam grade. Following the implementation of the EHEA framework, a change in the assessment process is required in the acquisition of competences and knowledge of the students (Gonzalez, Arquero \& Hassall, 2014), evolving to assessment methodologies that allow to take into account all the activities that the student performs in his learning process (Pascual, Camacho \& Müller, 2011).

The efficiency and effectiveness of different innovative teaching strategies have been tested within the framework of the Bologna Declaration in some accounting courses. Although the results showed students' satisfaction regarding these techniques, slight differences in performance are evidenced between students who passed the subject using these learning strategies with respect to those who did not use them (Beltrá, Pereira \& Sáez, 2011).

There are studies that state that, although at the beginning of the EHEA the students had a greater motivation with this type of evaluation, after the years of "consolidation" of this methodology there is a drop in the satisfaction that coincides with a greater workload by increasing the number of subjects taught simultaneously with this methodology (Oliveras, Crespo \& Raya, 2013).

In this context, continuous evaluation through online questionnaires, as a methodology that requires faster performance may be an alternative. Also, its automation in online platforms could be an advantage. Information and Communication Technologies (ICTs) are very useful in the teaching-learning process (UNESCO, 2008) and there have been numerous experiences of application in different subjects with very positive overall results (Swan, 2004; García-Benau \& Zorio-Grima, 2012). Indeed, there is a stream of research that analyses the integration of virtual learning environments (VLE, such as Blackboard or Moodle) in accounting courses (De Lange, Suwardy \& Mavondo, 2003; Broad, Matthews \& McDonald, 2004; Love \& Fry, 2006), the students' perceptions of VLE as compared to face-to -face learning (López Gavira \& Omoteso, 2013) or certain activities in VLE - e.g., Wells, De Lange \& Fieger (2008) find evidence that students are unwilling to participate in discussion forums and other two-way communications. Some studies conclude that lectures are using VLE as a supplementary tool to improve the broader teaching-learning environment, yet sometimes professors are perceived to be using the VLE just as a 'safety net' (Love \& Fry, 2006; Wells, De Lange \& Fieger, 2008). A very recent development of this line of research goes a step further: from a VLE to a personal learning environment (PLE). In a course using PLE, the teacher uses not only a virtual platform such as Moodle but also promotes the use of social networks and 2.0 technologies (see for instance the experience in business-related courses by Arquero \& Romero-Frías, 2013; Barrio-García, Arquero Montaño \& Romero-Frías, 2015; Arquero, del Barrio-García \& Romero-Frías, 2016).

In Financial Accounting, interactive questionnaires have been used as a selfassessment tool in different experiences (Martí Ballester \& Orgaz, 2011; Fuertes, Gil de Albornoz \& Viciano, 2015; Merello \& Zorio, 2016; Massoudi et al., 2017).

The implementation of interactive questionnaires has implications for the students and the faculty. Students must organize their time at home to complete the questionnaires requested by the teacher (Martí Ballester \& Orgaz, 2011). On the other hand, for the teacher it implies an extra effort in his teaching task as well as the need to get trained in the corresponding platforms (Durán et.al, 2015). As a result, it is even more necessary to assess the impact of this type of methodology and its cost-effectiveness. 
The results are inconclusive. Massoudi et al. (2017) find a positive relationship between formative online multiple choice questions and a better examination performance. However, Martí Ballester \& Orgaz (2011) find evidence that as the course advances and the complexity of the subject increases, the use of interactive questionnaires loses efficiency, and no improvement is observed for those students who take them over those who do not take them. Other results suggest that the performance of the online questionnaires is positive and significantly related to the performance in the final exam, although its marginal effect is lower than that of the partial exams. The relationship is only observed for students who pass the exam and in the parts containing questions of the same type as the questionnaires (Fuertes, Gil de Albornoz \& Viciano, 2015).

Other studies show that the satisfaction, frequency of use and utility variables of the virtual platforms have no influence on the final performance of the student nor on his/her attendance to class, so that these activities complement but do not replace face-to-face learning (Durán et al., 2015).

Specifically, in the area of business administration and management, positive experiences on the use of the Moodle platform as a specific VLE have been analysed (Escobar-Rodriguez \& Monge-Lozano, 2012). In this sense, some authors point out the interest of formative evaluation, which has also been evidenced in the accounting field (Einig, 2013).

Our work contributes to the literature in the sense that it identifies different types of students according to their performance evolution in the online tests and how some of the patterns can be identified as generating in some cases a dangerous overconfidence towards the final exam.

After this brief introduction, section 2 presents the objective and research questions, the teaching experience, the sample and the methodology used. Section 3 analyzes the results obtained. Finally, the main conclusions that can be drawn from this study are presented.

\section{MATERIALS AND METHOD}

\subsection{Objective and Research questions}

The objective of this paper is to evaluate the possible impact of the continuous assessment of the contents of the different thematic units of a financial accounting subject through questionnaires and using TICs (Moodle in this case) on the final exam.

The research questions we put forward in this study are as follows.

RQ1. Is the mark obtained in the test (or tests) of a specific unit (or units) directly related to a better performance in the final exam?

$R Q 2$. Are there different students' profiles depending on the evolution of their performance in the questionnaires?.

RQ3. Is a better (or worse) performance in the final exam related to a particular student profile?.

\subsection{Teaching experience}

The introduction of the Moodle platform as a teaching and evaluation tool has been implemented in a Financial Accounting course in the year 2015/2016. This subject is taken by first-year students of the Degree in Business Administration and Management of Valencia University. The evaluation of the subject is based on a final exam $(80 \%$ of the final mark in the subject) and a continuous assessment methodology (remaining $20 \%$ ) which includes a practical exercise test in the classroom (10\% final grade) and eight online questionnaires (one per unit) through Moodle (10\%). 
In the academic year $2015 / 2016$, the following final grades were obtained for the subject: $26.42 \%$ of the students made a no-show, $33.96 \%$ failed the subject (final grade $<5), 26.42 \%$ had passed (5th final grade $<7$ ) and $13.21 \%$ obtained a grade of good $(7 \leq$ final mark<9). No student in this group got the highest grade, i.e. excellent ( $9 \leq$ final mark $\leq 10)$. Note that the Spanish system has a grading system ranging from 0-10 points, requiring at least 5 points to pass the course.

The syllabus consists of 9 units. 8 units have been evaluated through online selfcorrective questionnaires in the Moodle platform, combining multiple-choice and true/false questions.

\subsection{Description of the sample}

The group of students in this course includes 53 students, $32 \%$ of which are women and $68 \%$ are men. $81 \%$ of the students are between $18-24$ years old, $9.43 \%$ between $25-29$, and the rest are over 30 years old. The $73.6 \%$ is the first time they take the subject, $15.1 \%$ re-take it for the second time and $11.3 \%$ of the students are taking it at least for the 3rd time.

During the $2015 / 2016$ academic year, $94.12 \%$ of women chose to follow the continuous assessment system (16/17) compared to $83.33 \%$ of men $(30 / 36)$. Of the total of 46 students who followed the continuous assessment method, only 39 showed up in the final exam (84.7\%).

\subsection{Variables and Data Analysis}

We use the Cluster Analysis in its hierarchical modality, whose main purpose is to group objects based on the characteristics they possess, trying to maximize the homogeneity of the objects within the clusters while at the same time maximizing the heterogeneity between the aggregates (Hair et al., 1999).

Also, Multiple Correspondence Analysis is implemented, as it is a procedure to summarize the information contained in a contingency table through an objective procedure of assigning numerical values to qualitative variables (Peña, 2002).

The Correspondence Analysis is a statistical technique that is used to analyse, from a graphical point of view, the dependency relations of a set of categorical variables from data of a contingency table. It is a exploratory method whose objective is to summarize a large amount of data in a small number of dimensions, with the least possible loss of information. Its objective is similar to that of factorial methods, but applied on categorical variables.

The qualitative character of the variables makes necessary using a distance different to the Euclidean.

$M$ is the total number of categories $\left(M=\sum_{k} m_{k}\right), m$ represents the categories of a variable $1,2, \ldots, m_{k}, \vee$ the variables $V_{1}, V_{2}, \ldots, V_{j}$; and $Q$ the number of variables $\sum_{i} k_{i j}=k_{i .}=Q$

Thus, the inertias due to each category j, the inertia of a variable (equal to the sum of the inertias of its categories) and the total inertia (sum of the inertias of all variables) are defined. Total inertia is defined as:

$$
I=\frac{M}{Q}-1
$$


The inertial matrices for columns and rows are diagonalized, obtaining their eigenvalues and eigenvectors, defining a space formed by the factors and the projection of the categories on it.

The new coordinates of the categories of the analyzed variables are obtained from the eigenvalues and eigenvectors. Through its graphic representation, it is possible to measure the degree of association and to represent it in a Cartesian diagram (perceptual map).

For the analysis of multiple correspondences, the average grade of the online tests and the grade of the final exam have been categorized into a variable with 4 categories (failed, pass, good, excellent). The equivalences are Failed $x<5$ (variable $=1$ ), Pass $5 \leq x$ $<7$ (variable $=2$ ), Good $7 \leq x<9$ (variable $=3$ ), Excellent $x \geq 9$ (variable $=4$ ).

\section{RESULTS}

\subsection{Pearson's correlation analysis}

A Pearson correlation analysis is performed considering as variables the final exam grade and the grade of each of the questionnaires (see Table 1). There was no significant correlation between the grade obtained in the final exam and the grade obtained in any of the 8 questionnaires. Therefore, we find no significant evidence that the test mark of a specific unit relates directly with a better performance on the final exam (RQ1).

Table 1. Pearson correlation matrix. ${ }^{*}$ The correlation is significant at 0.05 .

\begin{tabular}{|c|c|c|c|c|c|c|c|c|c|}
\hline & $\begin{array}{l}\text { Final } \\
\text { Exam }\end{array}$ & $\begin{array}{l}\text { Test } \\
\text { unit } 1\end{array}$ & $\begin{array}{l}\text { Test } \\
\text { unit } 2\end{array}$ & $\begin{array}{l}\text { Test } \\
\text { unit } 3\end{array}$ & $\begin{array}{l}\text { Test } \\
\text { unit } 4\end{array}$ & $\begin{array}{l}\text { Test } \\
\text { unit } 5\end{array}$ & $\begin{array}{l}\text { Test } \\
\text { unit } 6\end{array}$ & $\begin{array}{l}\text { Test } \\
\text { unit } 7\end{array}$ & $\begin{array}{l}\text { Test } \\
\text { unit } 8\end{array}$ \\
\hline $\begin{array}{l}\text { Final } \\
\text { Exam }\end{array}$ & 1 & & & & & & & & \\
\hline $\begin{array}{l}\text { Test } \\
\text { unit } 1\end{array}$ & 0.089 & 1 & & & & & & & \\
\hline $\begin{array}{l}\text { Test } \\
\text { unit } 2\end{array}$ & 0.184 & 0.197 & 1 & & & & & & \\
\hline $\begin{array}{l}\text { Test } \\
\text { unit } 3\end{array}$ & 0.295 & -0.150 & 0.008 & 1 & & & & & \\
\hline $\begin{array}{l}\text { Test } \\
\text { unit } 4\end{array}$ & 0.270 & -0.175 & 0.081 & $0.315^{*}$ & 1 & & & & \\
\hline $\begin{array}{l}\text { Test } \\
\text { unit } 5\end{array}$ & 0.069 & 0.042 & 0.099 & 0.022 & 0.086 & 1 & & & \\
\hline $\begin{array}{l}\text { Test } \\
\text { unit } 6\end{array}$ & 0.176 & 0.100 & 0.061 & 0.075 & 0.219 & -0.061 & 1 & & \\
\hline $\begin{array}{l}\text { Test } \\
\text { unit } 7\end{array}$ & -0.049 & -0.180 & -0.056 & -0.104 & 0.269 & 0.183 & $0.339 *$ & 1 & \\
\hline $\begin{array}{l}\text { Test } \\
\text { unit } 8\end{array}$ & 0.211 & 0.242 & 0.262 & -0.089 & 0.236 & 0.108 & 0.264 & 0.058 & 1 \\
\hline
\end{tabular}


Regarding the unit tests, there is significant and positive correlation between the performance on tests of the units 3 and $4(r=0.315$, sig=0.033), and of the units 6 and 7 $(r=0.339$, sig $=0.047)$. Note that these tests refer to consecutive but not specifically related thematic units: "accounting cycle" (unit 3) and "Inventories" (unit 4), "Nonfinancial fixed assets" (unit 6) and "Other financial assets and liabilities" (unit 7).

This may suggest that the variables that condition the results obtained in the test for each unit are not only related to contents but also to other variables such as the chronology of the course, the specific academic calendar of that course, the evolution of student motivation along the course, etc.

\subsection{Student profiles in continuous assessment}

A hierarchical cluster analysis is performed on the students performance, considering as classification variables the different grades obtained in each one of the questionnaires.

The Ward method is chosen to minimize the differences within the cluster and avoid problems with the allocation chaining. Among the different alternatives, in terms of the measure of similarity between objects, the square Euclidean distance has been chosen, since the variables are measured on a common scale (0 to 10). As mentioned above, there are no problems of multicollinearity in our sample.

After studying multiple solutions, a solution with three clusters has been chosen (Table 2) based on the distance coefficient, the dendogram and the interpretability of the student profiles. A good cluster solution is one that considers a sudden change in the distance coefficient.

Table 2. Cluster composition.

\begin{tabular}{|c|c|c|c|c|c|}
\hline Variable & Cluster 1 & Cluster 2 & Cluster 3 & Valid & Lost \\
\hline Test 1 & 7,22 & 8,19 & 7,04 & & \\
\hline Test 2 & 7,61 & 7,24 & 8,22 & & \\
\hline Tesł 3 & 6,73 & 6,81 & 6,58 & & \\
\hline Test 4 & 7,21 & N.P. & 8,06 & & \\
\hline Test 5 & 7,52 & 7,25 & 7,87 & & \\
\hline Test 6 & 6,75 & 7,00 & 7,41 & & \\
\hline Test 7 & 7,17 & 6,50 & 8,11 & & \\
\hline Test 8 & 5,25 & 6,33 & 9,48 & & \\
\hline Cases & 12 & 4 & 9 & 25 & 21 \\
\hline$\%$ cases & $48 \%$ & $16 \%$ & $36 \%$ & & \\
\hline
\end{tabular}




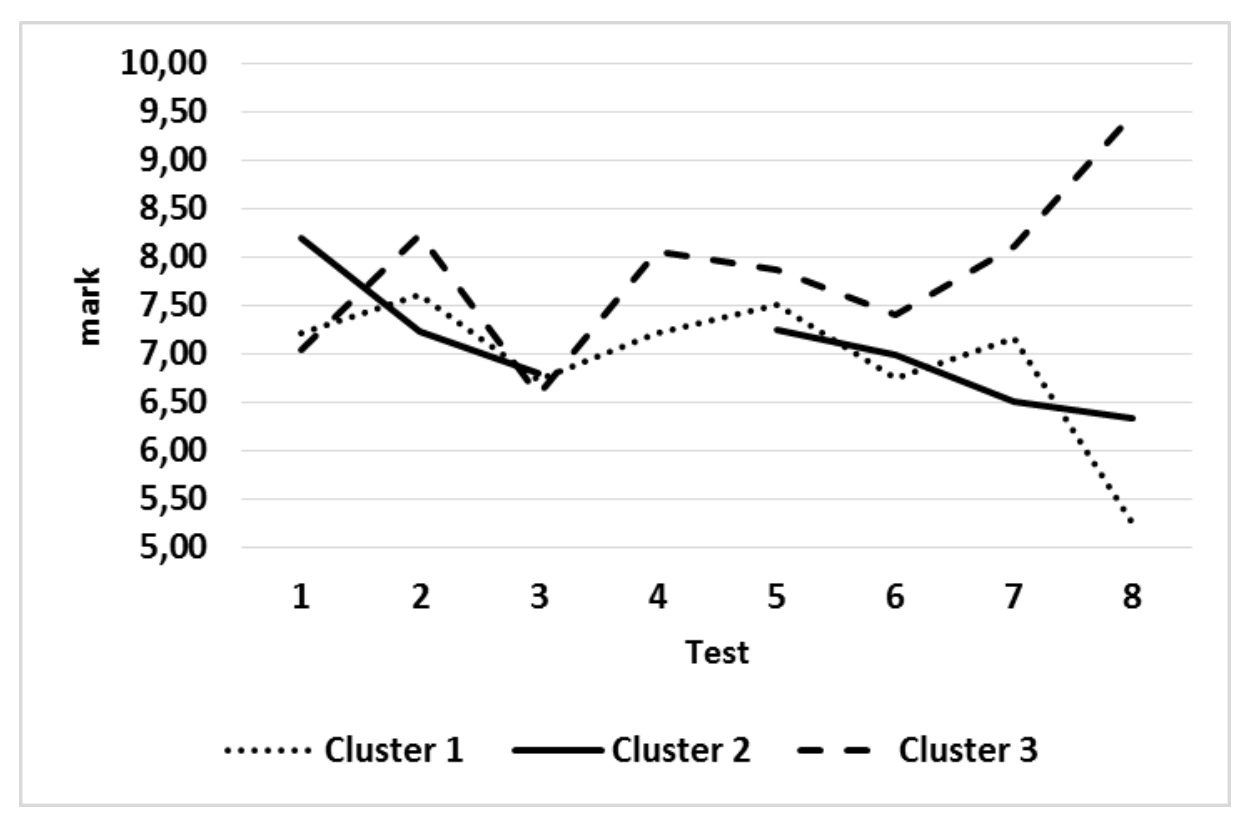

Figure 1. Evolution of the average mark per cluster.

Figure 1 shows that students in Cluster 1 and 2 have followed a decreasing trend in their results of the continuous assessment questionnaires (Table 2), compared to students in cluster 3 that are characterized by an increasing trend in their results of the questionnaires. The main difference between clusters 1 and 2 is that cluster 2 maintains a nearly constant decreasing trend (with no student taking test 4) and cluster 1 has a greater variability in the average test results.

As a robustness check, the analyses were replicated with the non-hierarchical method of the k-means obtaining similar results for all the clusters and questionnaires, except for thematic units 2 and 8 that present worse results in the cluster 3.

Likewise, for a more visual interpretation of the different clusters, the evaluation of the similarities between the different profiles of students (according to their results in the tests) and the categorization of the average grade obtained in the questionnaires has been performed with a multiple correspondence analysis.

A two-dimensional solution is selected due to the two first dimensions contribute to jointly explain the $100 \%$ of to the total inertia, being $59 \%$ the proportion of inertia explained by the dimension 1.

The row and column points have total contribution to inertia equal to 1, being the categories totally represented in the factors.

The results are presented on a perceptual map (Figure 2). The blue circle shows the 3 categories of average marks in the tests (failed, pass and good) and the green circle represents the profile student cluster (1,2 and 3, illustrated in Table 2 as well as in Figure 1).

The interpretation of the axes is as follows.

Regarding the students' profiles, dimension 1 fundamentally discriminates cluster 3 of clusters 1 and 2 , with scores in the dimension $0.902,-0.322$ and -1.065 respectively. Cluster 2 and 3 has not negligible relative contribution to inertia $(0.346$ and 0.559 , respectively) in dimension 1 . The dimension 2, fundamentally discriminates to cluster 1. 
Cluster 1 and 2 has not negligible relative contribution to inertia $(0.425$ and 0.494 , respectively) in dimension 1.

With regard to the categories of the average mark in the questionaries, dimension 1 discriminates the best results, having the category Good a positive score (0.743). The three categories has a not negligible relative contribution to inertia on dimension 1 $(0.315,0.221$ and 0.464 , respectively). Category Failed has a notable relative contribution to inertia (0.645) and a very negative score $(-2.656)$ in dimension 2.
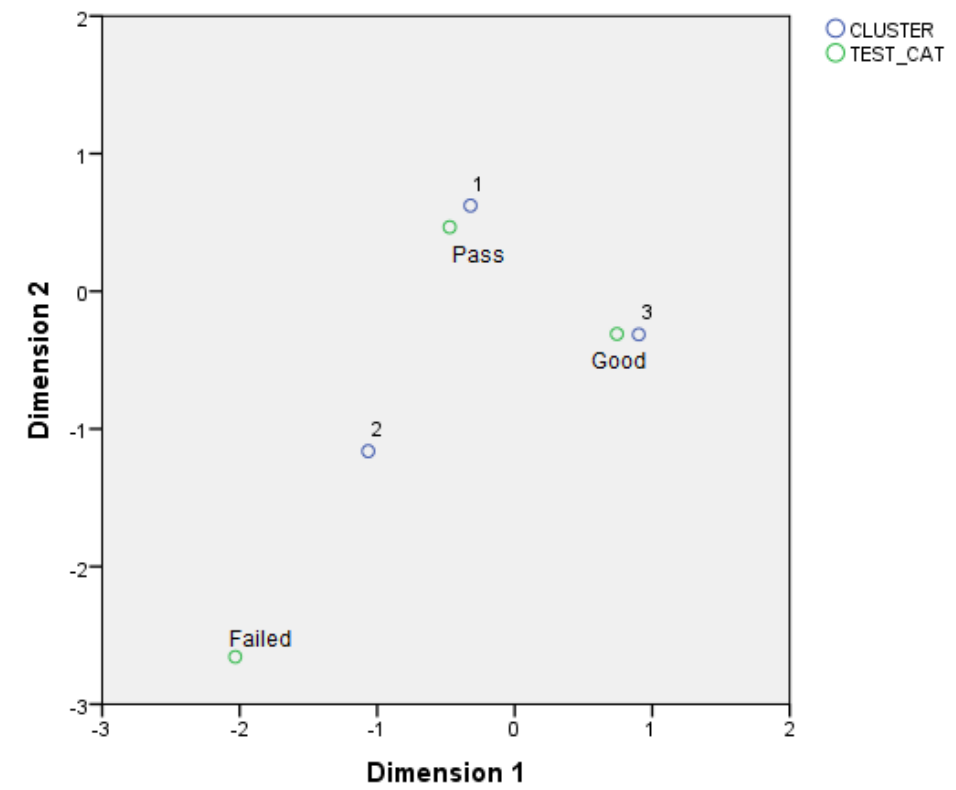

Figure 2. Perceptual map of the multiple correspondence analysis for the categorical variable Test and the result of the cluster analysis.

According to figure 2, and as expected, those students who obtain an average mark of good in the tests are mainly those in cluster 3, whereas those who do not take test 4 (cluster 2) are the closest to obtaining an average grade of failed, and those in cluster 1 are those that obtain an average grade of pass. Therefore, according to our RQ2, we can conclude that there are different students' profiles depending on the evolution of their performance in the questionnaires.

\subsection{Impact of students' performance in the continuous assessment through moodle on the final exam mark}

In this section, we look into the similarities between the different profiles of students (according to their result in the questionnaires) and their mark in the final exam through a multiple correspondence analysis. This analysis is useful in this case since it allows summarizing the similarities between different categorical variables, in our case the student's profile (clusters) and their performance in the final exam (categorized as Failed, Pass, Good and Excellent). The perceptual map (Figure 3) will help us identify the profile of students who achieve better results in the final exam.

The number of dimensions is selected based on the desired level of total explanation of the variation and the increase of explanation when adding an extra dimension. A twodimensional solution is the most suitable for further analysis in terms of interpretation and explanation, as the two first dimensions contribute to explain the $100 \%$ of to the total inertia. 
The proportion of inertia explained by each dimension also represents the importance of each of the dimensions when explaining the observed dependencies (Table 3).

Table 3. Dimensions and inertias.

\section{Proportion of inertia}

\begin{tabular}{lcccl}
\multicolumn{2}{l}{ DimensionEigenvaluelnertia } & & Cumulated \\
\hline 1 & 0.249 & 0.062 & 0.789 & 0.789 \\
2 & 0.129 & 0.017 & 0.211 & 1.000 \\
Total & & 0.078 & 1.000 & 1.000 \\
\hline
\end{tabular}

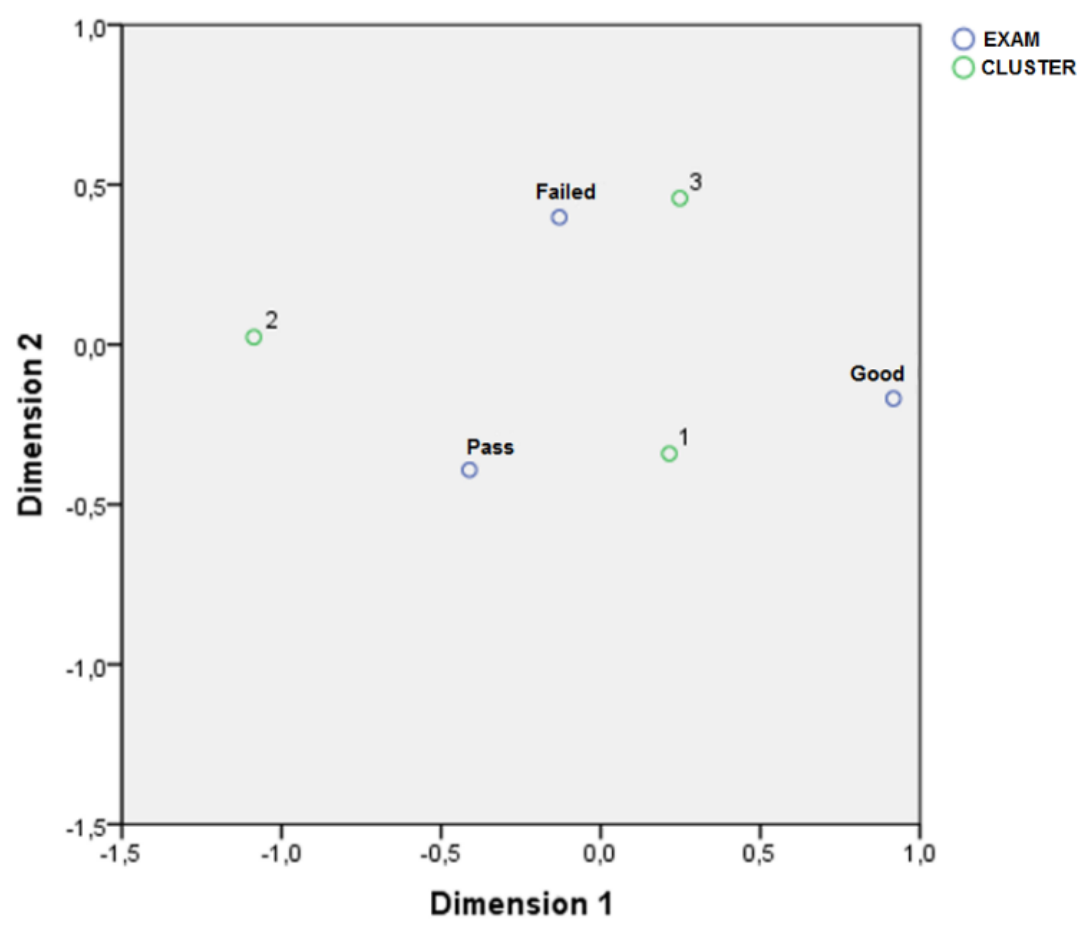

Figure 3. Perceptual map of the multiple correspondence analysis for the categorical variable Final exam and the result of the cluster analysis (student profile).

Note that dimension one condenses $78 \%$ of the inertia of the data (Table 3), so when determining similarities between the categories of different variables the closeness in this dimension will be determinant.

The interpretation of the axes is based upon the contributions of the categories.

Regarding the students' profiles, dimension 1 fundamentally discriminates cluster 2 of clusters 1 and 3 , with scores in the dimension 1.087, -0.215 and -0.248 respectively. Cluster 2 has an important relative contribution to inertia (0.825) in dimension 1 . The dimension 2, fundamentally discriminates to cluster 1 , which also has a not negligible relative contribution to inertia $(0.433)$.

With regard to the categories of the final exam mark, dimension 1 discriminates the best results, having the category Good a negative score and an important relative contribution to inertia (0.734). Dimension 2 discriminates the categories that represent an exam mark $<5$, having the category Failed a negative score. Categories Failed and 
Pass have not negligible relative contribution to inertia ( 0.536 and 0.416 , respectively) in dimension 2.

The analysis of the contributions of the row and column points reflects a total representativeness of the categories in the factors, with values equal to 1 in the total contribution to inertia.

Contrary to what might be considered as an initial hypothesis, the perceptual map shows that there is a relationship between those students who belong to cluster 3 and category 1 of the final exam mark (failed). Smolin \& Butakov (2014) look into this paradox, i.e. the inconsistency between in-class performance and the performance in the final exam. On the other hand, there is also a certain similarity between the students in cluster 1 and category 2 of the final exam result (pass). Therefore, according to our $R Q 3$, a worse performance in the final exam is related to a particular student profile i.e., surprisingly those students with a more positive evolution in the specific unit tests along the course.

Category 3 of the exam mark (good) is not specifically related to any student profile.

This result could indicate that there is an inverse relationship between the trend in the results obtained in the continuous assessment by a student and the probability of passing the final exam.

\section{DISCUSSION AND IMPLICATIONS OF RESEARCH}

In the context of incorporating the ICTs to the formative evaluation of the students, it seems extremely relevant to evaluate if an improvement on students' performance is really and efficiently achieved. The literature describes the different learning styles of the students (Escobar-Rodriguez \& Monge-Lozano, 2012) and how different methodologies can be useful to respond to that variety. However, in accounting, there is no extant research on the existence of different patterns of knowledge level evolution, nor on the impact of these patterns on a final exam. Some studies, however, point out the possibility that in certain contexts overconfidence can arise depending on certain variables - such as the previous domain of technology or gender (Gunn and McSporran, 2003).

According to existing research, there are mixed results regarding the impect of online questionnaires on the final exam in accounting courses (Martí Ballester \& Orgaz, 2011; Fuertes, Gil de Albornoz \& Viciano, 2015; Massoudi et al., 2017). The findings of our study evidence that there are different students' profiles depending on the evolution of their performance in the questionnaires and that a worse performance in the final exam is related to a particular student profile- i.e, surprisingly as it may be, those students who have improved their performance in the final units tests.

Further research is needed in order to find out if this overconfidence effect can be produced due to the final exam focuses on practical contents and the continuous assessment questionaries focus on theoretical questions. As suggested in previous literature (Fuertes, Gil de Albornoz \& Viciano, 2015), positive and significantly relation to the performance in the final exam is only observed in the parts containing questions of the same type as in the questionnaires.

Therefore, our findings suggest new avenues for research on the results of these new teaching methodologies using larger samples and more variables that may allow to identify the characteristics of the students with this profile, in order to try to avoid these undesired consequences of the instrument. Could the relationship identified with failure in the final exam be attributed to certain emotional factors such as overconfidence? Does the tendency for a worsening of the continuous assessment mark encourage the student to make a greater study effort for the final exam? 


\section{REFERENCES}

ARQUERO, J. L., DEL BARRIO-GARCÍA, S., \& ROMERO-FRÍAS, E. (2016). What Drives Students' Loyalty-Formation in Social Media Learning Within a Personal Learning Environment Approach? The Moderating Role of Need for Cognition. Journal of Educational Computing Research, 0735633116672056.

ARQUERO, J. L., \& ROMERO-FRÍAS, E. (2013). Using social network sites in Higher Education: an experience in business studies. Innovations in Education and Teaching International, 50(3), 238-249.

BARRIO-GARCÍA, S. D., ARQUERO MONTAÑO, J. L., \& ROMERO-FRÍAS, E. (2015). Personal learning environments acceptance model: The role of need for cognition, e-learning satisfaction and students' perceptions. Educational Technology \& Society, 18(3), 129141.

BELTRÁ, J. L., PEREIRA, J. M., \& SÁEZ, J. L. (2011). Practical application of alternative teaching methods in Accounting. EDUCADE, The Spanish Journal of Accounting, Finance and Management Education, 2, 3-34.

BROAD, M., MATTHEWS, M., \& MCDONALD, A. (2004). Accounting education through an online-supported virtual learning environment. Active Learning in Higher Education, 5(2), 135-151.

DE LANGE, P., SUWARDY, T., \& MAVONDO, F. (2003). Integrating a virtual learning environment into an introductory accounting course: determinants of student motivation. Accounting Education, 12(1), 1-14.

DURÁN, P., MASIDE, J. M., RODEIRO, D., \& CANTORNA, S. (2015). Academic performance and use of virtual learning environments for students of a curse of accounting. EDUCADE. The Spanish Journal of Accounting, Finance and Management Education, 6, 5-21.

EINIG, S. (2013). Supporting Students' Learning: The Use of Formative Online Assessments. Accounting Education, 22 (5), 425-444.

ESCOBAR-RODRIGUEZ, T., \& MONGE-LOZANO, P. (2012). The acceptance of Moodle technology by business administration students. Computers \& Education, 58(4), 1085 1093.

EUROPEAN MINISTERS OF EDUCATION (1999). The Bologna Declaration of 19 June 1999 Joint declaration of the European Ministers of Education. Available at: http://www.ond.vlaanderen.be/hogeronderwijs/bologna/documents/MDC/BOLOG NA_DECLARATION1.pdf Accessed on 28/01/2016.

FUERTES, I., GIL DE ALBORNOZ, B., \& VICIANO, J. J. (2015). Do online quizzes enhance performance in a summative assessment? An experience in the area of Accounting. EDUCADE, The Spanish Journal of Accounting, Finance and Management Education, 6, 35-57.

GARCÍA-BENAU, M. A., \& ZORIO-GRIMA, A. (2012). Experience on the Use of a Mix of Teaching Methods in Higher Education of Accounting. Cuadernos de Contabilidad, 13(33), 613-657.

GONZÁlEZ, J. M. G., MONTAÑO, J. L. A., \& HASSALL, T. (2009). Bologna and beyond: A comparative study focused on UK and Spanish accounting education. Higher Education in Europe, 34(1), 113-125.

GONZALEZ, J. M., ARQUERO MONTANO, J. L., \& HASSALL, T. (2014). The change towards a teaching methodology based on competences: a case study in a Spanish university. Research Papers in Education, 29(1), 111-130. 
GUNN, C. \& MCSPORRAN, M. (2003). Dominant or different? Gender issues in computer supported learning. Journal of Asynchronous Learning Networks, 7(1), 14-30.

HAIR, J. F., ANDERSON, R. E., TATHAM, R. L., \& BLACK, W.C. (1999). Análisis multivariante. Madrid, Spain: Prentice Hall lberia.

LOVE, N., \& FRY, N. (2006). Accounting students' perceptions of a virtual learning environment: Springboard or safety net?. Accounting Education: an international journal, 15(2), 151-166.

LÓPEZ GAVIRA, R., \& OMOTESO, K. (2013). Perceptions of the usefulness of virtual learning environments in accounting education: A comparative evaluation of undergraduate accounting students in Spain and England. Accounting Education, $22(5), 445-466$.

MARTí BALLESTER, C. P., \& ORGAZ, N. (2011). Interactive questionnaires as selfassessment tool for accounting Subjects. EDUCADE, The Spanish Journal of Accounting, Finance and Management Education, 2, 51-66.

MASSOUDI, D., KOH, S. K., HANCOCK, P., \& FUNG, L. (2017). The Effectiveness of Usage of Online Multiple Choice Questions on Student Performance in Introductory Accounting. Issues in Accounting Education. Online early. https://doi.org/10.2308/iace-51722

MERELLO-GIMÉNEZ, P., \& ZORIO-GRIMA, A. (2016). Moderating role of gender in the performance of Moodle questionnaires in an introductory Accounting course. Procedia - Social and Behavioral Sciences, 228, 407-412.

OLIVERAS, E., CRESPO, P., \& RAYA, J. M. (2013). The Bologna process in accounting: effects on students satisfaction. EDUCADE. The Spanish Journal of Accounting, Finance and Management Education, 4, 22-33.

PASCUAL, D., CAMACHO, M. M., \& MÜLLER, A. (2011). Are the new EHEA assessment methods appropriate to evaluate the academic performance of students? An experience in Financial Accounting. EDUCADE, The Spanish Journal of Accounting, Finance and Management Education, 2, 67-83.

PEÑA, D. (2002). Análisis de datos multivariantes. Madrid, Spain: McGraw-Hill.

SMOLIN, D., \& BUTAKOV, S. (2014). Resolving the Paradox of Overconfident Students with Intelligent Methods. In U. Kose, and D. Koc. (Eds.), Artificial Intelligence Applications in Distance Education (pp. 161-174). Hershey, USA: IGI Global.

SWAN, K. (2004). Learning online: A review of current research on issues of interface, teaching presence and learner characteristics. In J. Bourne \& J. Moore (Eds.), Elements of quality online education, 5, 63-79.

UNESCO (2008). Estándares de competencias en TIC para docentes. Available at: http://www.oei.es/tic/UNESCOEstandaresDocentes.pdf. Accessed on the $27 / 01 / 2016$

WELLS, P., DE LANGE, P., \& FIEGER, P. (2008). Integrating a virtual learning environment into a second-year accounting course: determinants of overall student perception. Accounting \& Finance, 48(3), 503-518. 